\title{
DIVERSITY AND SPATIAL DISTRIBUTION OF SOIL CYANOBACTERIA ALONG AN ALTITUDINAL GRADIENT IN MARRAKESH AREA (MOROCCO)
}

\author{
HAKKoum, Z. ${ }^{1}$ - MinAOUI, F. ${ }^{1}$ - DOUMA, M. ${ }^{1,2}-$ Mouhri, K. ${ }^{1}$ - LOUdIKI, M. ${ }^{1 *}$ \\ ${ }^{1}$ Laboratory of Water, Biodiversity and Climate Change; Phycology, Biotechnology and \\ Environmental Toxicology Research Unit, Faculty of Sciences Semlalia Marrakesh, Cadi Ayyad \\ University, Av. Prince My Abdellah P.O. Box 2390, Marrakesh 40000, Morocco \\ (e-mails:zineb.hakkoum@gmail.com,minaoui.farah@gmail.com) \\ ${ }^{2}$ Polydisciplinary Faculty of Khouribga (FPK), Sultan Moulay Slimane University, Khouribga, \\ Morocco \\ (e-mail: douma_mountasser@yahoo.fr; phone: +212-661-967-057) \\ *Corresponding author \\ e-mail: loudiki@uca.ac.ma; phone: +212-670-099-329; fax: +212-524-436-769; ORCID: \\ https://orcid.org/0000-0002-3624-9225
}

(Received 27 $7^{\text {th }}$ Mar 2020; accepted $7^{\text {th }}$ Jul 2020)

\begin{abstract}
Cyanobacteria, are a photoautotrophic component of soil biological crusts in arid areas. They have attracted increasing interest worldwide due to their potential applications in agriculture biofertilization, rehabilitation of soil environments, biotechnology, natural products and medicine. However, biocrust cyanobacteria are not well investigated in North African countries where drylands are dominant. This study aims to explore the soil cyanobacterial diversity, to isolate interesting strains and to investigate the effect of soil properties and land use on their distribution in the Marrakesh area (Morocco). The sampling of biocrusts and measurement of soil physicochemical characteristics were done at five sampling sites during two campaigns. The morphological characterization of cyanobacterial strains was done by direct microscopy and soil culture inoculums in nutrient media. A total of 26 taxa were identified. Oscillatoriales constituted the most diversified order (84.62\%), followed by Chroococcales (11.54\%) and Nostocales (3.84\%). Three species are reported for the first time in Morocco. Six strains were isolated in soil culture in nutrient media. The results showed that the distribution of cyanobacteria was mainly influenced by humidity, soil texture, land use and vegetation cover. This survey provides a first inventory and data ecology of the soil cyanobacterial assemblages in the Moroccan mountainous region needed for understanding their potential in biotechnological restoration and in agricultural biofertilization.
\end{abstract}

Keywords: biocrust cyanobacteria, taxonomy, ecology, edaphic factors, High Atlas Mountains

\section{Introduction}

Cyanobacteria are the oldest photoautrophic component of Biological Soil Crusts communities (BSCs) which include bacteria, algae, fungi, lichens and mosses (RiveraAguilar et al., 2006; Maestre et al., 2011). These biocrusts occur on and within the top centimeters of the soil surface all over the world, including the most hostile environments like extremely arid and dryland areas where cyanobacteria are often the most important primary producers (Hoffmann, 1989; Heckman et al., 2006; Belnap et al., 2016).

Cyanobacteria play a key role in carbon and $\mathrm{N}$-cycling, nutrient dynamics, and ecosystem productivity (Hackl et al., 2004). They furnish nutrients to the soil as a good bio-fertilizer and stabilize soil structure by the production of the extracellular polysaccharides that aggregate soil particles, and sometimes increase their porosity and 
water-holding capacity (Liu et al., 2017). Most filamentous cyanobacteria are responsible for biocrust formation and are also the most abundant component in some soil types (Janatková et al., 2013).

Their many adaptations allow them to colonize unstable substrates and their presence may also enhance the ecological role and biocrust functions (Garcia-Pichel et al., 2009; Büdel et al., 2016). Due to their oxygenic photosynthesis and capability to fix carbon, atmospheric nitrogen and solubilize phosphate compounds, the bio-prospecting of cyanobacteria is increasing for their potential use in agriculture bio-fertilization (Singh et al., 2014; Rossi et al., 2017), restoration and rehabilitation of soil environments (Acea et al., 2001; Malam Issa et al., 2007).

Cyanobacteria has also gained immense interest due to its natural products and various secondary metabolites, including vitamins, enzymes, and pharmaceuticals substances (Hu et al., 2008). Moreover, these microorganisms have been identified as a rich source of biologically active compounds with antiviral, antibacterial, antifungal and anticancer activities (Abed et al., 2009).

Although several researches have shown that cyanobacteria are a precious bio-resource in agriculture, ecosystem, and environmental sustainability (Singh et al., 2016; Bag et al., 2019), studies on cyanobacterial diversity of biocrusts have begun only recently and more than 320 species are known to occur in biocrusts on different continents.

However, in Africa, data about the diversity of biocrust cyanobacteria remains fragmentary and strongly heterogenous between the different regions. Although Africa is one of the largest continents with considerably larger dryland areas, only 83 cyanobacteria species have been reported in biocrusts (Büdel et al., 2016). In the Northern part of Africa with larger arid and hyperarid landscapes, little is known about the biocrusts communities who are still underexplored and where there is a need for much more biodiversity assessments.

At the local scale, abiotic factors other than climate may control the type of biocrusts present. Soils properties such as moisture and texture, nutrient content, land use and vegetation cover are extremely important. Also, the species composition of biocrust community could be regulated by anthropogenic activities and environmental stressors across temporal and spatial scales (Belnap et al., 2016).

In Morocco, a Northwest African arid and semiarid country, cyanobacteria are well studied in aquatic ecosystems (Loudiki et al., 2002; Douma et al., 2009). However, soil cyanobacteria of biocrusts have not yet been explored and require further attention, especially in mountains such as the High Atlas and the hyperarid and desert southern areas. Soil environments in high-altitude ecosystems provide habitats for numerous cyanobacteria despite being related to extreme environmental pressures, such as freezing and desiccation (Kastovská et al., 2005; Nemergut et al., 2007; Blanco et al., 2012).

Biodiversity of soil cyanobacteria in high mountains biocrusts and their geographical distribution have received great attention worldwide (Řeháková et al., 2011). In Mediterranean dryland ecosystems, known by their fragility and vulnerability, many studies showed that biocrust cyanobacteria play a crucial role in their ecological functioning and improve both erosion protection and biofertilization of soils (Zancan et al., 2006; Maestre et al., 2011).

Therefore, this work explored the soil cyanobacteria biodiversity in the high mountains of a Moroccan area (High Atlas of Marrakesh) along an altitudinal gradient, aiming to identify and isolate some interested taxa and to assess the effect of different environmental variables in the distribution of soil cyanobacteria. 


\section{Material and methods}

\section{Study area}

The study was conducted in the Ourika watershed $\left(31^{\circ} \mathrm{N}\right.$ and $31^{\circ} 21^{\prime} \mathrm{N}, 7^{\circ} 30^{\prime} \mathrm{W}$ and $\left.7^{\circ} 60^{\prime} \mathrm{W}\right)$ located in the High Atlas Mountain, at $40 \mathrm{~km}$ south of Marrakesh city, Morocco (Fig. 1). The watershed covers an area of $576 \mathrm{~km}^{2}$ and has an altitude of 1070$4000 \mathrm{~m}$. Its bioclimate is semi-arid to sub-humid from the lower altitudinal to the higher mountain parts. Its average rainfall varies from 450 to more than $650 \mathrm{~mm}$ on the piedmont and from 800 to $1000 \mathrm{~mm}$ on the high summits. The vegetation cover of the basin is scattered and quite degraded and forests occupy only $35.6 \%$ of which $25 \%$ are open forests dominated by green oak, thuja and juniper. More than half of the basin area has no forest cover with $49.74 \%$ for spiny xerophytes and $13.86 \%$ for bare soil and crops (Fig. 1). The data on land use, vegetation type and cover in the Ourika basin were documented by Ouhammou (2005), Haroni et al. (2009), Meliho et al. (2016) and Nduwayo et al. (2017).

This mountainous basin is very sparsely populated and the built-up area plus the river beds account for only $0.78 \%$. Food crops occupy only $7 \%$ and cattle and goat breeding is the most dominant in some valleys. The pastoral activity and grazing are also developed especially in high altitude areas such as Oukaimeden.

The study area is located in a natural mountainous zone from the granitic highlands of Oukaimeden (2634 m) to sedimentary Haouz arid plain (765 m).

\section{Sampling sites and soil sampling}

Five sampling sites located in different zones along an altitudinal and vegetation gradient (from a high mountain to arid steppe) were prospected. These sampling sites were selected based on different land use type including grassland, open forest, moderately dense forest, shrub land and steppe land (Fig. 1). Table 1 provides the sampling sites characteristics and their vegetation type.

Table 1. Sampling sites characteristics

\begin{tabular}{|c|c|c|c|c|c|c|}
\hline Sampling sites & Coordinates & $\begin{array}{l}\text { Altitude } \\
\quad \text { (m) }\end{array}$ & $\begin{array}{c}\text { Climate } \\
\text { (Ouhammou, 2005) }\end{array}$ & $\begin{array}{l}\text { Nature of the } \\
\text { substrate }\end{array}$ & $\begin{array}{l}\text { Vegetation cover } \\
\text { (Haroni et al., } \\
\text { 2009) }\end{array}$ & $\begin{array}{c}\text { Land use } \\
\text { (Nduwayo et al., } \\
\text { 2017) }\end{array}$ \\
\hline $\begin{array}{c}\text { Site1: } \\
\text { Oukaimeden }\end{array}$ & $\begin{array}{l}\text { N: } 31^{\circ} 11.620^{\prime} \\
\mathrm{W}: 007^{\circ} 51.207^{\prime}\end{array}$ & 2634 & Wet and humid & $\begin{array}{c}\text { Eruptive, } \\
\text { metamorphic and } \\
\text { ancient rocks of } \\
\text { phanerozoic }\end{array}$ & $\begin{array}{l}\text { Spiny xerophytes, } \\
\text { peeler, asylvatic } \\
\text { zone }\end{array}$ & $\begin{array}{c}\text { Grassland, } \\
\text { pasture land and } \\
\text { bare land }\end{array}$ \\
\hline $\begin{array}{l}\text { Site 2: } \\
\text { Aleppo Pine } \\
\text { forest }\end{array}$ & $\begin{array}{c}\mathrm{N}: 31^{\circ} 15,754^{\prime} \\
\mathrm{W}: 007^{\circ} 49.226^{\prime}\end{array}$ & 1565 & Wet and humid & $\begin{array}{l}\text { Red sandstone of } \\
\text { Permotrias }\end{array}$ & $\begin{array}{l}\text { Clear forest } \\
\text { reforestation of } \\
\text { Aleppo pine }\end{array}$ & Forest land \\
\hline $\begin{array}{c}\text { Site 3: } \\
\text { Green Oak Forest } \\
\text { (Quercus ilex) }\end{array}$ & $\begin{array}{c}\mathrm{N}: 31^{\circ} 18.565^{\prime}, \\
\mathrm{W}: 007^{\circ} 45,340^{\prime}\end{array}$ & 1111 & $\begin{array}{l}\text { Semiarid to } \\
\text { subhumid }\end{array}$ & $\begin{array}{l}\text { Schistose-type } \\
\text { formation and } \\
\text { conglomerates }\end{array}$ & Green Oak forest & Shrub land \\
\hline $\begin{array}{c}\text { Site } 4: \\
\text { Barbary thuja } \\
\text { forest (Tetraclinis } \\
\text { articulata) }\end{array}$ & $\begin{array}{l}\mathrm{N}: 31^{\circ} 20.991^{\prime} \\
\mathrm{W}: 007^{\circ} 45.876^{\prime}\end{array}$ & 935 & $\begin{array}{l}\text { Semiarid to } \\
\text { subhumid }\end{array}$ & $\begin{array}{c}\text { Conglomerate, } \\
\text { Permotrias sandstone, } \\
\text { salt rocks, clay soil }\end{array}$ & $\begin{array}{l}\text { Dense vegetation, } \\
\text { Thuja, red } \\
\text { Juniperus, } \\
\text { Oxycedrus, green } \\
\text { oak }\end{array}$ & Forest land \\
\hline $\begin{array}{c}\text { Site 5: } \\
\text { Jujube steppe } \\
\text { (Ziziphus lotus) of } \\
\text { Haouz }\end{array}$ & $\begin{array}{l}\mathrm{N}: 31^{\circ} 25.224^{\prime} \\
\mathrm{W}: 007^{\circ} 50.237^{\prime}\end{array}$ & 765 & Arid & Sedimentary substrate & $\begin{array}{l}\text { Steppe with } \\
\text { Zizyphus lotus }\end{array}$ & $\begin{array}{c}\text { Steppe land and } \\
\text { bare soil }\end{array}$ \\
\hline
\end{tabular}




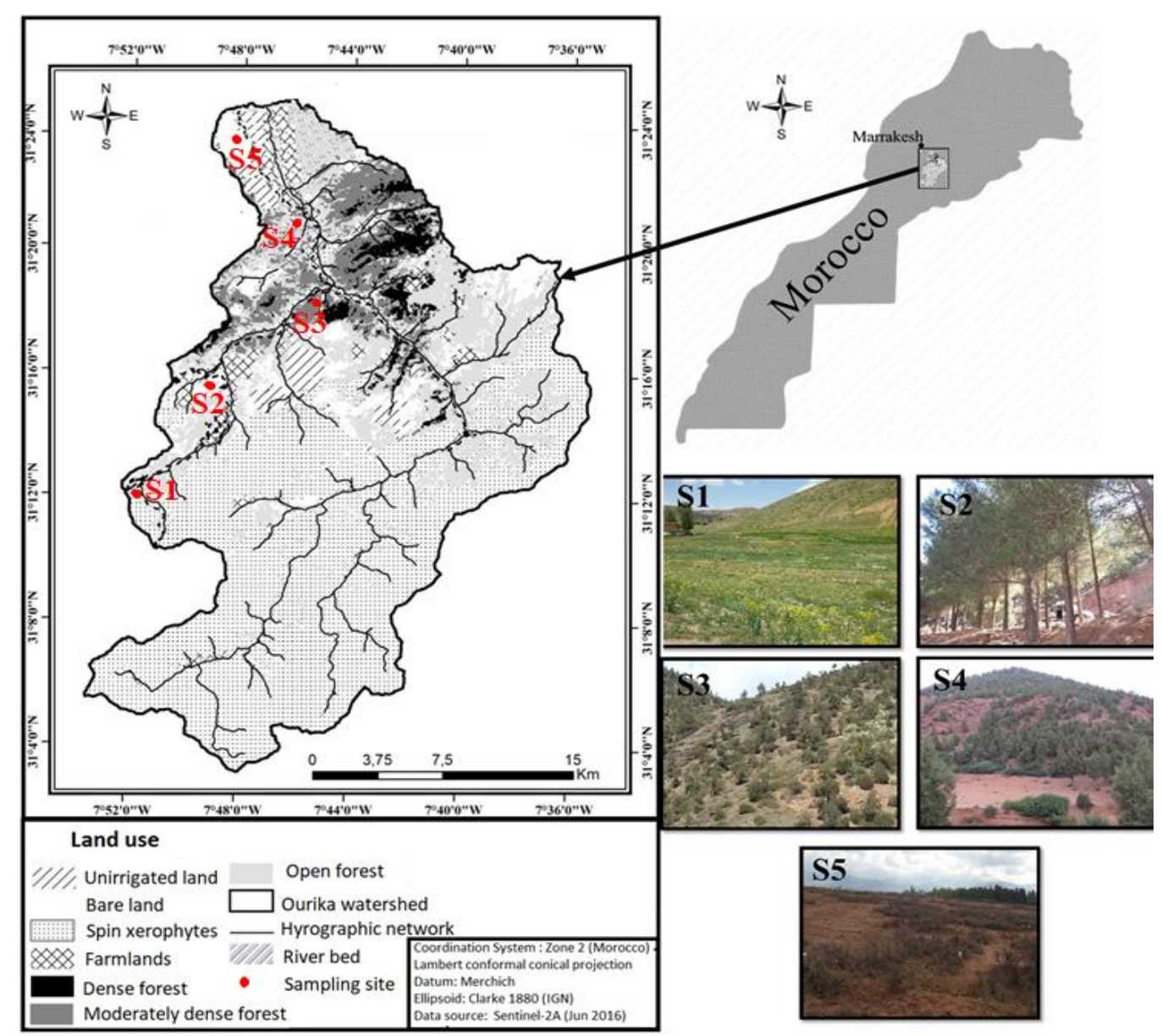

Figure 1. Location of sampling sites in Ourika basin. S1: Oukaimeden; S2: Aleppo Pine Forest; S3: Green Oak Forest; S4: Thuja forest; S5: Haouz arid steppe. (The land use map of the Ourika basin is carried out by Nduwayo et al., 2017; modified figure)

In each sampling site, we performed two soil samples during two campaigns (February $14^{\text {th }}$ and May $4^{\text {th }}$ of 2016). A composite biocrust samples (made up of number of smaller samples of $10 \mathrm{~cm}^{2}$ and $1-3 \mathrm{~cm}$ deep) were taken randomly with a sterile spatula. At each site, an area of 500-1000 $\mathrm{m}^{2}$ was explored to choose the representative points developed biocrusts, showing a range of colonization states, from early successional (lightly pigmented: light biocrusts) to late successional (darkly pigmented: dark biocrusts) (Belnap et al., 2008), avoiding those dominated by moss or lichen, as previously described by Garcia-Pichel et al. (2016). In total, 50 soil samples ( 5 sites $\times$ 10 replicates) were collected in sterilized Petri-dishes $(90 \mathrm{~mm}$ diameter $)$ for cyanobacterial microscopy examination, culturing and isolation. A second composite sample, for physicochemical analysis, was taken from the upper bare surface layer (1$3 \mathrm{~cm}$ ) of soil according to Řeháková et al. (2011). This last sample was placed in clean polyethylene bags and kept at $4{ }^{\circ} \mathrm{C}$ until further analysis.

\section{Soil physico-chemical characteristics}

In the laboratory, the soil samples were sieved $(<2 \mathrm{~mm})$ and air-dried at room temperature for physico-chemical analysis (El Khalil et al., 2013). All soil analyses 
were conducted on the $<2 \mathrm{~mm}$ size fraction according to NF ISO 10390. A conductivity meter (Cond 1970i WTW GmbH, Weilheim, Germany) was used to measure the electrical conductivity. $\mathrm{pH}$ was assessed using a $\mathrm{pH}$ meter $(\mathrm{pH}$ 1970i WTW GmbH, Weilheim, Germany). The method of Anne (Aubert, 1978) was used to determinate total organic carbon. This method allows to evaluate the organic matter content of soil samples. Available phosphorus was measured by the Olsen method (Olsen et al., 1954). The content of ammoniacal nitrogen $\left(\mathrm{N}_{-} \mathrm{NH}_{4}{ }^{+}\right)$was determined according to the norm instructions (AFNOR, 1975). Soil moisture was measured gravimetrically according to the standard method (AFNOR, 2000). The soil samples were oven-dried at $105^{\circ} \mathrm{C}$ for $48 \mathrm{~h}$ based on the oven drying method. The soil texture of samples was obtained using the classic method (Soltner, 2005). The soil chlorophyll a content was performed by boiling ethanol extraction after cleaning all vascular plants (ISO, 1992).

\section{Taxonomic identification of cyanobacteria}

The morphological identification of cyanobacterial taxa was carried out using both field and cultured material (Mansour and Shaaban, 2010).

The representative subsamples of biocrusts, were selected, mixed together, and homogenized to form a composite sample (Muñoz-Martín et al., 2019). A suspension of each biocrust sample was prepared by dissolution of $1 \mathrm{~g}$ of mixed soil diluted $10 \mathrm{ml}$ fold in sterilized distilled water. A few drops of this suspension were immediately examined using research light microscope (Motic BA210, China; 400× and 1000× magnification) to make a preliminary identification of the cyanobacteria present taxa. Then, they were identified using recent cyanobacteria monographs (Anagnostidis and Komarek, 1990; Komarek and Anagnostidis, 1998, 2005; Komarek, 2013).

\section{Strain isolation and culture conditions of cyanobacteria}

After sieving and grinding soil samples, a series of 5 dilutions ranged from $10^{-1}$ to $10^{-5}$ were prepared. Under aseptic conditions, $1 \mathrm{ml}$ of the soil suspension of each dilution was inoculated in triplicate on solid (1.5\% agar) and then on liquid media. Z8 medium was used for the strain isolation and growth (Kotai, 1972). The cultures were maintained under controlled conditions (temperature $26^{\circ} \mathrm{C} \pm 1$, light intensity $60 \mu \mathrm{mol} . \mathrm{m}^{-2} \cdot \mathrm{s}^{-1}$, light dark cycle of $15 / 9$ with continuous aeration) for 8 to 12 days. After cyanobacteria growth, a series of successive transplants of the isolated strains onto new medium were made to obtain monoalgal and purified culture. Monoalgal strains were used for profound morphological identification of species under the light microscopy (Motic BA210, China) using the imaging software analysis (Motic Images + 2.0).

\section{Data analysis}

All soil parameters analysis was done in three replicates. The results are expressed as mean \pm standard Error (SE). One-way analysis of variance (ANOVA) with the Tukey test was used to determine the differences between sampling sites. The significance of the results was compared at $\mathrm{p}<0.05$.

A multivariate analysis was performed to identify correlations between different cyanobacteria taxa and soils properties using a Principal Component Analysis (PCA). In the data matrix, the individuals are the sampling sites; the variables are the cyanobacteria taxa and the average of physico-chemical parameters. A hierarchical 
classification was made from the coordinates of individuals and variables to establish a soil typology and assess the degree of similarity of the investigated sites.

The statistical analysis was performed by XLSTAT 2016 version 18.02.01.27444; Addinsoft, France.

\section{Results}

\section{Soil physico-chemical parameters}

The comparison of soils physico-chemical parameters showed spatiotemporal variations and significant differences $(p<0.05)$ were observed between soils in different land uses (Table 2). The $\mathrm{pH}$ values were slightly acidic to neutral ranging between 6.49 and 7.90 and decreasing significantly $(\mathrm{p}<0.05)$ with altitude. The low altitude sites (S3, S4, S5) have slightly neutral to alkaline values, while the grassland high altitudinal one (S1) has slightly acidic value.

Electrical conductivity also showed a significant decreasing gradient $(\mathrm{p}<0.05)$ with altitude. The highest values were registered in low lands, with 380 and $257.5 \mu \mathrm{S} / \mathrm{cm}$ in $\mathrm{S} 3$ and S5, respectively. While, the high land (S1) showed the minimal value $(69.15 \mu \mathrm{S} / \mathrm{cm})$. Indeed, the Oukaimeden grassland soil was significantly less mineralized $(p<0.05)$ compared to other soils.

In all the sites, the soil moisture ranged from 3 to $8.9 \%$ with higher values and a relative stability in February campaign (8.45-8.9\%), whereas it decreased in May campaign (up to 3\%), especially at S2, S3 and S4. The soil moisture of grassland (S1) was significantly higher $(\mathrm{p}<0.05)$ than the other land uses.

During the two campaigns, the total organic carbon content varied from 2.16 to $4.66 \%$ and showed a significant difference between different soils. Soils from lower forest and steppe lands (S3, S4, S5) have the highest concentration of total organic carbon. Ammonia nitrogen and available phosphorus contents were very low and fairly similar with often no significant difference between sites. The soil texture is clay in all sites, except sites 1 and 3 where it is silty clay and clay silt, respectively.

\section{Soil biotic indicator}

On May $4^{\text {th }}$, the soil algal biomass, assessed by chlorophyll a content, increased significantly $(\mathrm{p}<0.05)$ along the altitudinal gradient, varying from $10.48 \mu \mathrm{g} / \mathrm{g}$ soil at site 5 to $31 \mu \mathrm{g} / \mathrm{g}$ soil at sites 1 and 2 (Fig. 2). Unlike the February campaign, the chlorophyll a concentration increased significantly $(\mathrm{p}<0.05)$ in May and showed a clear spatial disparity with higher level measured at the two altitudinal sampling sites.

\section{Cyanobacterial diversity: identification and strain isolation}

In all studied sites, a total of 26 cyanobacteria taxa were identified (Table 3), belonging to 3 orders, 8 families and 9 genera (Fig. 3b). Oscillatoriales constitute the most diversified order with 84.62 of all taxa, followed by Chroococcales (11.54\%) and Nostocales (3.84\%) (Table 4). The three genera Leptolyngbya (7 taxa), Phormidium (6 taxa), Pseudanabaena (6 taxa) are the most represented (Fig. 3c). In order of occurrence, the common species present in most soil crusts were Nostoc muscorum (5 sites), Phormidium crassivaginatum (4 sites), Leptolyngbya faveolarum (3 sites); while Leptolyngbya sp 1 and Leptolyngbya sp 2 were represented in some specific soils (2 sites). The highest number of taxa (12 taxa) were observed in the highly altitude station 
(S1) (Fig. 3a). Based on the most updated Moroccan checklist of cyanobacteria (Douma, 2010), three species are reported for the first time in Morocco (Phormidium priestleyi, Phormidium crassivaginatum, Pseudanabaena minima) (Fig. 4). It should be noted that for many taxa (10 in total), morphological taxonomic identification was stopped at the genera level. Further modern identification techniques (polyphasic approach) remain necessary to accurately confirm the identity of these taxa. Six species of soil cyanobacteria were successfully isolated from the studied soils and culturing in laboratory. These species were Phormidium articulatum, Nostoc muscorum, Lyngbya sp Pseudanabaena sp1, Leptolyngbya sp1 and Synechocystis sp1 (Fig. 4).

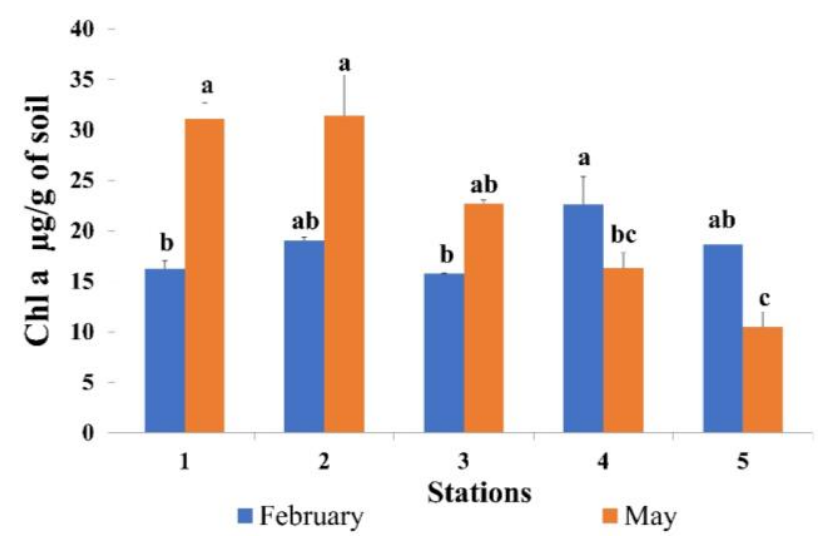

Figure 2. Chlorophyll a concentration ( $\mu \mathrm{g} / \mathrm{g}$ soil) in the studied soils. Data are means \pm standard error $(n=3)$. Different letters indicate significant differences $(p<0.05$ by

Tukey's HSD test) between sampled sites
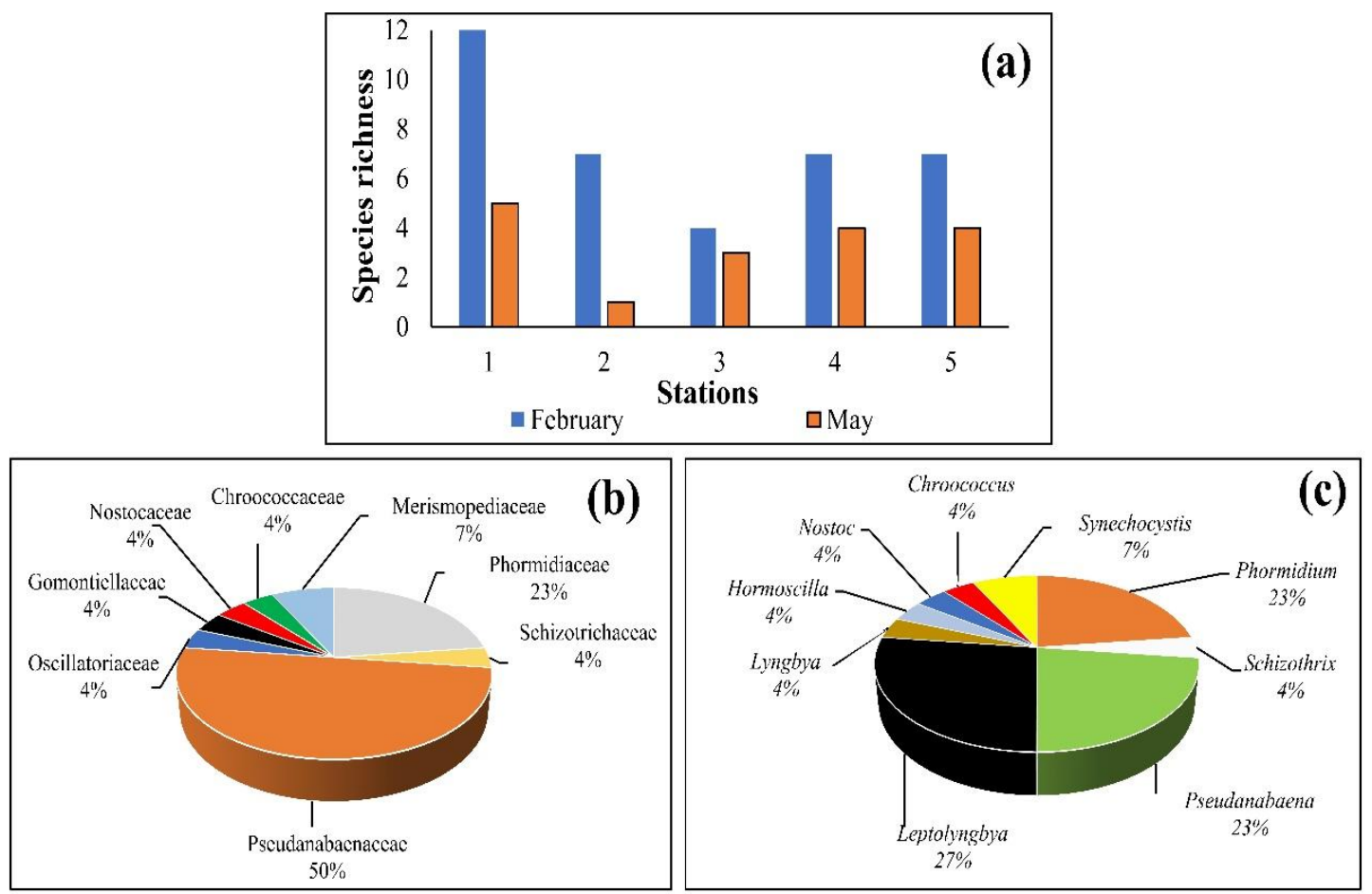

Figure 3. Species richness (a), spectrum families (b) and spectrum genera (c) of cyanobacteria in the studied soils 
Table 2. Physico-chemical characteristics of sampled soils

\begin{tabular}{|c|c|c|c|c|c|c|c|c|c|c|}
\hline \multirow{2}{*}{ Parameter } & \multicolumn{2}{|c|}{ Site 1} & \multicolumn{2}{|c|}{ Site 2} & \multicolumn{2}{|c|}{ Site 3} & \multicolumn{2}{|c|}{ Site 4} & \multicolumn{2}{|c|}{ Site 5} \\
\hline & $\mathbf{F}$ & M & $\mathbf{F}$ & M & $\mathbf{F}$ & M & $\mathbf{F}$ & M & $\mathbf{F}$ & M \\
\hline $\mathrm{pH}$ & $6.98 \pm 0.08^{\mathrm{c}}$ & $6.49 \pm 0.085^{\mathbf{c}}$ & $7.22 \pm 0.005^{\mathbf{b c}}$ & $7.90 \pm 0.056^{\mathrm{a}}$ & $7.80 \pm 0.05^{\mathrm{a}}$ & $7.73 \pm 0.296^{\mathrm{a}}$ & $7.47 \pm 0.03^{\text {ab }}$ & $7.29 \pm 0.014^{\mathrm{b}}$ & $7.42 \pm 0.39^{\mathrm{abc}}$ & $7.83 \pm 0.025^{\mathrm{a}}$ \\
\hline $\mathrm{CE}$ & $120 \pm 10^{\mathrm{d}}$ & $69.2 \pm 2.35^{\mathrm{d}}$ & $73.15 \pm 0.15^{\mathrm{e}}$ & $185.7 \pm 0.45^{\mathrm{a}}$ & $380 \pm 6^{\mathbf{a}}$ & $157.6 \pm 0^{b}$ & $139.4 \pm 0.75^{\mathbf{c}}$ & $161.2 \pm 0.2^{\mathbf{b}}$ & $257.5 \pm 7.5^{\mathbf{b}}$ & $101.7 \pm 1.9^{\mathbf{c}}$ \\
\hline $\mathrm{H}$ & $8.9 \pm 0.01^{\mathrm{a}}$ & $7.7 \pm 0.06^{\mathbf{a}}$ & $7.4 \pm 0.01^{\mathrm{c}}$ & $3 \pm 0.14^{b}$ & $8.6 \pm 0.03^{b}$ & $4.4 \pm 0.09^{b}$ & $8.7 \pm 0.02^{b}$ & $3 \pm 0.06^{\mathbf{b}}$ & $8.5 \pm 0.02^{\mathrm{c}}$ & $8.7 \pm 0.05^{\mathbf{c}}$ \\
\hline TOC & $3.02 \pm 0.15^{\mathrm{e}}$ & $2.16 \pm 0.16^{\mathrm{e}}$ & $3.28 \pm 0.43^{\mathrm{d}}$ & $2.91 \pm 2.31^{\mathrm{c}}$ & $3.33 \pm 1.33^{\mathrm{c}}$ & $2.66 \pm 0.66^{d}$ & $4.66 \pm 0.66^{\mathbf{a}}$ & $4.33 \pm 1.2^{\mathrm{a}}$ & $4.16 \pm 1.01^{b}$ & $3.83 \pm 0.72^{\mathbf{b}}$ \\
\hline $\mathrm{P}_{-} \mathrm{PO}_{4}$ & $0.039 \pm 0^{\mathrm{ab}}$ & $0.007 \pm 0.021^{\mathrm{c}}$ & $0.039 \pm 0.004^{\mathrm{ab}}$ & $0.006 \pm 0.012^{\mathrm{c}}$ & $0.034 \pm 0.001^{b}$ & $0.004 \pm 0.003^{\mathrm{d}}$ & $0.045 \pm 0.004^{\mathrm{a}}$ & $0.034 \pm 0.039^{\mathrm{a}}$ & $0.038 \pm 0.001^{\text {ab }}$ & $0.016 \pm 0.031^{\mathrm{b}}$ \\
\hline $\mathrm{N}-\mathrm{NH}_{4}{ }^{+}$ & $0.029 \pm 0.002^{\mathrm{a}}$ & $0.040 \pm 0.001^{\mathrm{a}}$ & $0.014 \pm 0.002^{\mathbf{b}}$ & $0.033 \pm 0.001^{\mathbf{b}}$ & $0.017 \pm 0.001^{b}$ & $0.032 \pm 0.001^{\mathbf{b}}$ & $0.032 \pm 0.005^{\mathrm{a}}$ & $0.025 \pm 0.001^{\mathrm{c}}$ & $0.016 \pm 0^{\mathbf{b}}$ & $0.022 \pm 0.001^{\mathrm{c}}$ \\
\hline Texture & \multicolumn{2}{|c|}{ Silty clay } & \multicolumn{2}{|c|}{ Clay } & \multicolumn{2}{|c|}{ Clay silt } & \multicolumn{2}{|c|}{ Clay } & \multicolumn{2}{|c|}{ Clay } \\
\hline
\end{tabular}

The values are denoted as mean \pm standard error $(n=3)$. Different letters indicate significant differences $(\mathrm{p}<0.05$ by Tukey's HSD test) between sampled sites. EC:

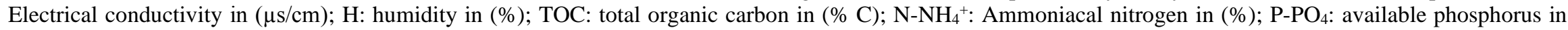
(mg/g soil). F: February; M: May

Table 3. Inventory of cyanobacteria taxa in the study sites (F: February; M: May)

\begin{tabular}{|c|c|c|c|c|c|c|c|c|c|c|}
\hline \multirow{2}{*}{ Taxa } & \multicolumn{2}{|c|}{ S 1} & \multicolumn{2}{|c|}{ S 2} & \multicolumn{2}{|c|}{ S 3} & \multicolumn{2}{|c|}{ S 4} & \multicolumn{2}{|c|}{ S 5} \\
\hline & $\mathbf{F}$ & $\mathbf{M}$ & $\mathbf{F}$ & $\mathbf{M}$ & $\mathbf{F}$ & $\mathbf{M}$ & $\mathbf{F}$ & $\mathbf{M}$ & $\mathbf{F}$ & $\mathbf{M}$ \\
\hline $\begin{array}{l}\text { Order/Oscillatoriales } \\
\text { F/Phormidiaceae }\end{array}$ & & & & & & & & & & \\
\hline Phormidium priestleyi Fri. (PPRI) & $\mathrm{X}$ & & & & & & & & & \\
\hline Phormidium crassivaginatum An. et Kom. (PCRA) & $\mathrm{X}$ & & $\mathrm{X}$ & & & & $\mathrm{X}$ & $\mathrm{X}$ & & $\mathrm{X}$ \\
\hline Phormidium Kuetzingianum An. (PKUE) & $\mathrm{X}$ & & & & & & & & & \\
\hline Phormidium molle Gom. (PMOL) & $\mathrm{X}$ & $\mathrm{X}$ & & & & & & & & \\
\hline Phormidium articulatum Clau. (PART) & & & & & $\mathrm{X}$ & $\mathrm{X}$ & $\mathrm{X}$ & $\mathrm{X}$ & & \\
\hline Phormidium paulsenianum (Boy.) Nov. (PPAU) & & & & & & & & & $\mathrm{X}$ & \\
\hline F/Schizotrichaceae & & & & & & & & & & \\
\hline Schizothrix sp (Ssp) & & & & & & & & & $\mathrm{X}$ & \\
\hline F/Pseudanabaenaceae & & & & & & & & & & \\
\hline
\end{tabular}

APPLIED ECOLOGY AND ENVIRONMENTAL RESEARCH 18(4):5527-5545.

http://www.aloki.hu • ISSN 15891623 (Print) • ISSN 17850037 (Online)

DOI: http://dx.doi.org/10.15666/aeer/1804_55275545

○ 2020, ALÖKI Kft., Budapest, Hungary 


\begin{tabular}{|c|c|c|c|c|c|c|c|c|c|c|}
\hline Pseudanabaena starmachii An. (PSTA) & $\mathrm{X}$ & & & & & & & & & \\
\hline Pseudanabaena minima An. (PMIN) & $\mathrm{X}$ & $\mathrm{X}$ & & & & & & & & \\
\hline Pseudanabaena moniliformis Kom. (PMON) & & & $\mathrm{X}$ & & & & & & & \\
\hline Pseudanabaena balatonica Sche. And Kol. (PBAL) & & & & & & & $\mathrm{X}$ & $\mathrm{X}$ & & \\
\hline Pseudanabaena galeata Böch. (PGAL) & & & & & & & & & $\mathrm{X}$ & $\mathrm{X}$ \\
\hline Pseudanabaena sp 1 (Psp) & $\mathrm{X}$ & & & & & & & & & \\
\hline Leptolyngbya lurida (Gom.) An. et Kom. (Llur) & $\mathrm{X}$ & & & & & & & & & \\
\hline Leptolyngbya faveolarum (Rab.) An. et Kom. (LFAV) & $\mathrm{X}$ & $\mathrm{X}$ & & & $\mathrm{X}$ & $\mathrm{X}$ & $\mathrm{X}$ & $\mathrm{X}$ & & \\
\hline Leptolyngbya tenuis (Gom.) An. et Kom. (LTEN) & & & & & & & & & $\mathrm{X}$ & \\
\hline Leptolyngbya pseudovalderiana (Vor.) An. et Kom. (LPSE) & & & & & & & & & $\mathrm{X}$ & $\mathrm{X}$ \\
\hline Leptolyngbya $\mathrm{sp} 1$ (Lsp1) & $\mathrm{X}$ & $\mathrm{X}$ & & & $\mathrm{X}$ & $\mathrm{X}$ & & & & \\
\hline Leptolyngbya sp 2 (Lsp2) & $\mathrm{X}$ & $\mathrm{X}$ & $\mathrm{X}$ & $\mathrm{X}$ & & & & & & \\
\hline Leptolyngbya sp 3 (Lsp3) & & & $\mathrm{X}$ & & & & & & & \\
\hline \multicolumn{11}{|l|}{ F/Oscillatoriaceae } \\
\hline Lyngbya sp (LYsp) & & & & & & & & & $\mathrm{X}$ & $\mathrm{X}$ \\
\hline \multicolumn{11}{|l|}{ F/Gomontiellaceae } \\
\hline Hormoscilla sp (Hsp) & & & & & & & $\mathrm{X}$ & & & \\
\hline \multicolumn{11}{|l|}{$\begin{array}{c}\text { O/Nostocales } \\
\text { F/Nostocaceae } \\
\end{array}$} \\
\hline Nostoc muscorum Ag. (NMUS) & $\mathrm{X}$ & & $\mathrm{X}$ & & $\mathrm{X}$ & & $\mathrm{X}$ & & $\mathrm{X}$ & \\
\hline \multicolumn{11}{|l|}{$\begin{array}{l}\text { O/Chroococcales } \\
\text { F/Chroococcaceae }\end{array}$} \\
\hline Chroococcus sp (Csp) & & & $\mathrm{X}$ & & & & & & & \\
\hline \multicolumn{11}{|l|}{ F/Merismopediaceae } \\
\hline Synechocystis sp 1 (Ssp1) & & & & & & & $\mathrm{X}$ & & & \\
\hline Synechocystis sp 2 (Ssp2) & & & $\mathrm{X}$ & & & & & & & \\
\hline Total of taxa/site & 12 & 5 & 7 & 1 & 4 & 3 & 7 & 4 & 7 & 4 \\
\hline
\end{tabular}


Table 4. Importance of taxonomic level of cyanobacteria in studied soils

\begin{tabular}{c|c|c|c|c}
\hline \multirow{2}{*}{ Order (O/) } & \multicolumn{4}{|c}{ Taxonomic level } \\
\cline { 2 - 5 } & Family & Genera & Species & Total (\%) \\
\hline O/Oscillatoriales & 5 & 6 & 22 & 84.62 \\
O/Chroococcales & 2 & 2 & 3 & 11.54 \\
O/Nostocales & 1 & 1 & 1 & 3.84 \\
Total & 8 & 9 & 26 & 100 \\
\hline
\end{tabular}

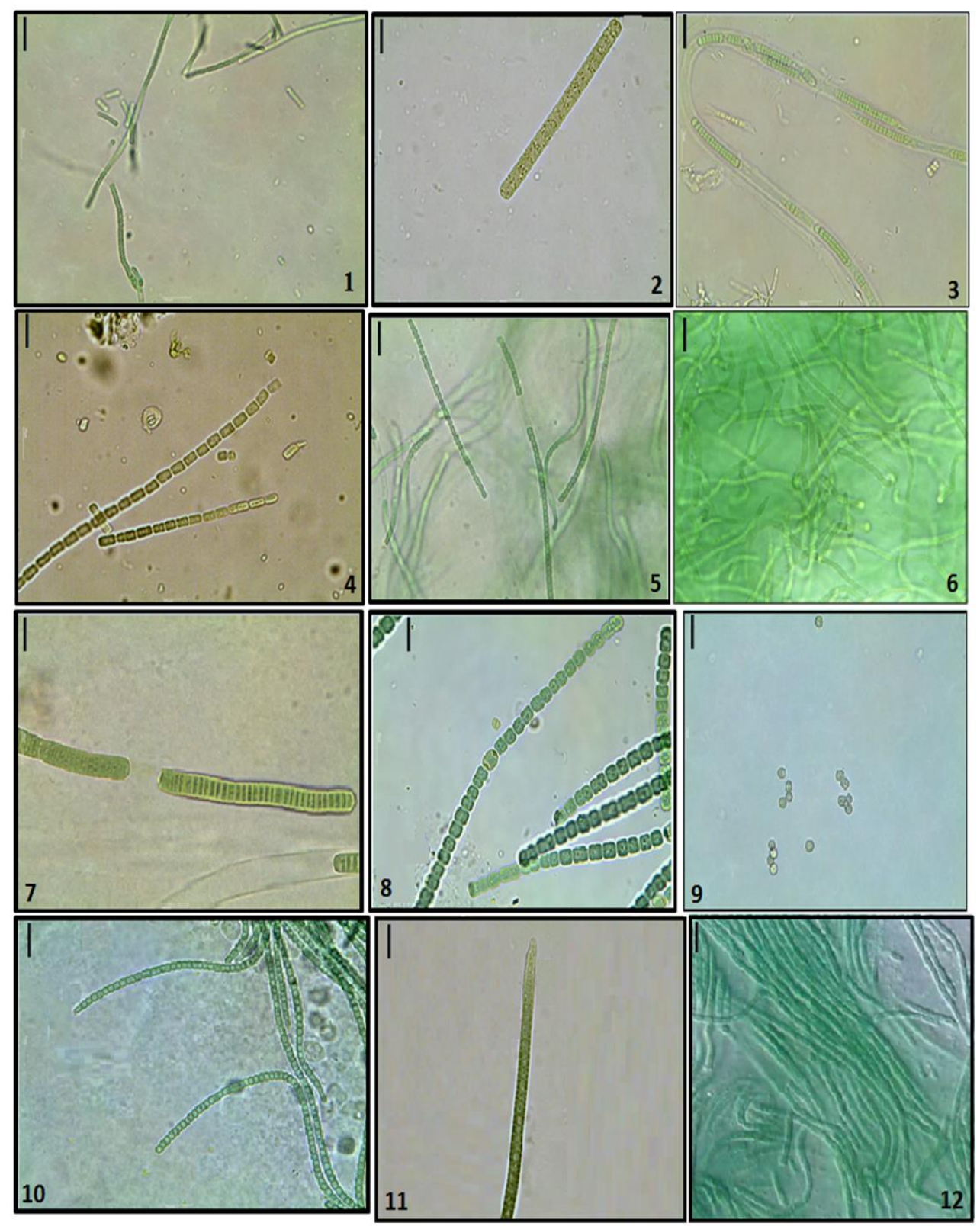

Figure 4. Microphotographs of identified cyanobacterial strains. 1: Phormidium priestleyi; 2: Phormidium Kuetzingianum; 3: Schizothrix sp; 4: Pseudanbaena minima; 5: Pseudanabaena balatonica; 6: Leptolyngbya faveolarum; 7: Lyngbya sp; 8: Nostoc muscorum; 9: Synechocystis sp 1; 10: Phormidium articulatum; 11: Phormidium crassivaginatum; 12: Leptolyngbya sp 1. Scale Bar $=10 \mu$ 


\section{Multivariate analyses}

A principal component analysis (PCA) was performed on a data matrix consisting of 8 variables (humidity, $\mathrm{pH}$, conductivity, total organic carbon, available phosphorus, ammonia nitrogen, granulometry, chlorophyll a) and 26 individuals (taxa) distributed along the five studied sites (Fig. 5). The variables were mainly correlated with two axes (F1 and F2) in which $53.86 \%$ of the total variance in the data was found.

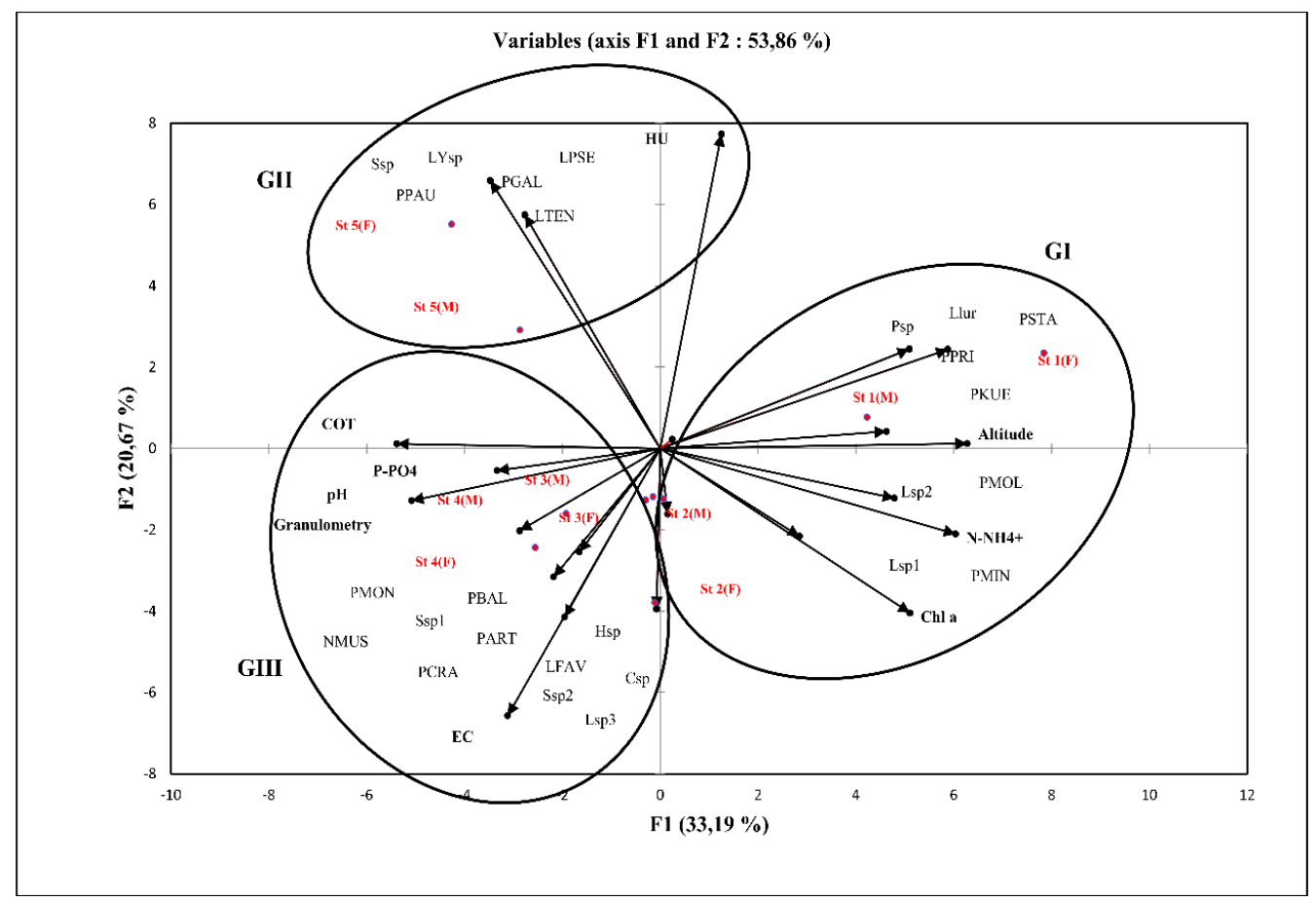

Figure 5. Projection of variables (physicochemical parameters and cyanobacteria taxa) and sampling sites (in red) on the factorial level $\left(\begin{array}{lll}1 & x & 2\end{array}\right)$

The first axis F1 with $33.19 \%$ of total variance was strongly correlated on the positive side with ammonia nitrogen, chlorophyll a and altitude. The second axis F2 with $20.67 \%$ was positively formed in correlation with humidity. The PCA analysis results revealed that the group of taxa Phormidium priestleyi (PPRI), Phormidium Kuetzingianum (PKUE), Phormidium molle (PMOL), Pseudanabaena starmachii (PSTA), Pseudanabaena minima (PMIN), Pseudanabaena sp1 (Psp), Leptolyngbya lurida (Llur), Leptolyngbya sp2 (Lsp2) and Leptolyngbya sp1 (Lsp1) showed the highest correlation to ammonia nitrogen $\left(\mathrm{N}_{-} \mathrm{NH}_{4}{ }^{+}\right)$, chlorophyll a (Chl a) and altitude. However, the group of taxa Phormidium paulsenianum (PPAU), Schizothrix sp (Ssp), Pseudanabaena galeata (PGAL), Leptolyngbya tenuis (LTEN), Leptolyngbya pseudovalderiana (LPSE) and Lyngbya sp (LYsp) has the highest correlation to humidity (HU). A third group of taxa Phormidium articulatum (PART), Phormidium crassivaginatum (PCRA), Pseudanabaena moniliformis (PMON), Synechocystis sp2 (Ssp2), Chroococcus sp (Csp), Nostoc muscorum (NMUS), Leptolyngbya sp3 (Lsp3), Pseudanabaena balatonica (PBAL), Hormoscilla sp (Hsp), Synechocystis sp1 (Ssp1) and Leptolyngbya faveolarum (LFAV) has the highest association to $\mathrm{pH}$, conductivity (EC), available phosphorus content $\left(\mathrm{P}^{-} \mathrm{PO}_{4}^{-}\right)$, total organic carbon (COT) and granulometry. 
Furthermore, cluster analysis was performed to separate the taxa into distinct groups based on environmental factors. Three groups of taxa could be distinguished from the dendrogram based on the hierarchical cluster (Fig. 6):

I. Taxa with positive correlation to ammonia nitrogen, chlorophyll a and altitude; and with negative correlation to $\mathrm{pH}$ and total organic carbon. This first group is associated with the taxa of sites 1 and 2 .

II. Taxa with highest correlation to humidity. This second group is composed of the taxa from site 5.

III. Taxa with positive correlation to $\mathrm{pH}$, conductivity, available phosphorus content and granulometry. This third group brings together taxa from sites 3 and 4 .

The results of the data analysis revealed that nutrient content (ammonia nitrogen, available phosphorus), altitude, humidity, $\mathrm{pH}$ and conductivity were the main factors influencing the spatial distribution of cyanobacteria communities along the studied altitudinal gradient.

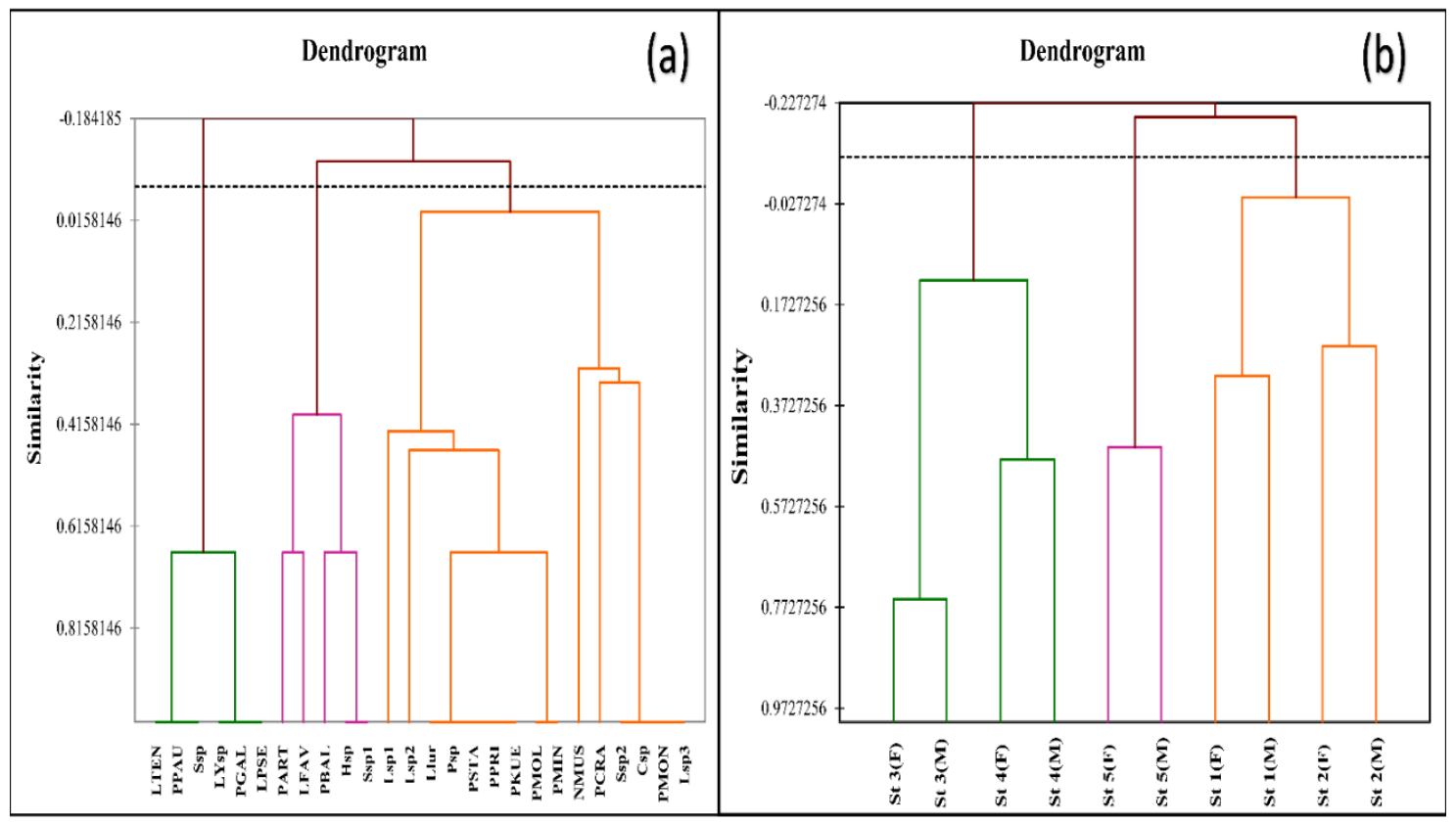

Figure 6. Cluster dendrogram of cyanobacteria groups (a) and the sampling sites (b) based on physico-chemical parameters

\section{Discussion}

The biomass of BSCs was mainly created by cyanobacterial and microalgal taxa, which are important primary producers within soil crusts all around the world (Janatková et al., 2013). The species composition, abundance and distribution of cyanobacteria biocrusts were influenced by various ecological and edaphic factors (Davey and Rothery, 1993). All the physico-chemical analyses and biological data (Table 2) showed that the characteristics of the soils along the natural altitudinal transect (S5 to S1) were mainly influenced by the substrate type, topographic and climatic conditions, land use and vegetation cover (e.g. grassland, forest land, shrub land, steppe land). These environmental factors induce a spatial variability in the soil moisture, texture and chemical composition. Compared to forest and steppe land, the 
soil of altitudinal grassland was slightly acidic, relatively wetter, weakly mineralized, and very poor in organic carbon and nutrients.

The obtained results show that cyanobacteria taxa exist in all studied soils, but they reveal a significant presence, especially in altitudinal grassland soil (S1). These results are in agreement with certain studies confirming that this group of microorganisms has an extraordinary resistance to extreme conditions in high altitudes (Řeháková et al., 2011). However, this observation is in contrast with other research, which suggest that cyanobacterial diversity is negatively correlated with acidity and altitude (Choudhary and Singh, 2013).

It is known that various cyanobacteria have a large ecological distribution and seem to be frequent both in high and low altitude soils. Our results showed that many cyanobacteria are ubiquitous and were inventoried at least in four different sites. Among these taxa we found Phormidium crassivaginatum, Leptolyngbya faveolarum and Nostoc muscorum. The cyanobacterial distribution and diversity in soil are the result of the complex influence of substrate, soil properties, vegetation type and climatic conditions (Quesada et al., 1998).

In this study, it was observed that the highest number of cyanobacteria was recorded in clay-silty soils (S1). This is consistent with the study of Kobbia et al. (1988) which shows that the clay soil has a high water retention and is suitable for the growth of cyanobacteria (Haider et al., 2017). The PCA analysis results revealed that humidity was among the main factors influencing the distribution of cyanobacterial communities along the studied altitudinal gradient. It was also noticed that the highest moisture value was measured in grassland soil $(8.89 \%)$ which appears to be less affected by temporal variations of rainfall compared to other soil land uses. This result corroborates that of Niu et al. (2015) which showed that soil moisture condition was affected by different land uses and that the higher soil moisture content was exhibited by the grassland followed by cropland, forest land and shrub land. Our observations have confirmed that land use plays a key role in controlling spatial and temporal variations of soil moisture as well as the soil water dynamic. Therefore, water content in soil plays a very important role in the distribution and diversity of soil microalgae (Lin et al., 2013). This situation helps cyanobacteria to keep a longer period of metabolic activity and accumulate more biomass (Zhang et al., 2011).

Furthermore, soil mineralization also influences distribution of soil cyanobacteria. In the studied altitudinal transect, the average values of conductivity were rather low ranging between 73.15 and $380 \mu \mathrm{S} / \mathrm{cm}$. These values are smaller than those recorded in Iraq $(233.8 \mu \mathrm{S} / \mathrm{cm}-3072 \mu \mathrm{S} / \mathrm{cm})$ (Haider et al., 2017). It is known that salinity leads to a decrease in the growth of cyanobacteria, but its effect on growth inhibition varies from one species to another given their morphological and molecular diversity. Consequently, the distribution of cyanobacteria in various environments is not equal, due to their adaptability and tolerance to extreme conditions such as saline environments (Rejmánková et al., 2004).

The studied soils were characterized by relatively low nitrogen, phosphorus and high organic matter content. Our results are similar to those of Zancan et al. (2006). Previous studies have shown that the concentration and quality of nutrients are probably more important in the blue-green-algal diversity. Vijayan and Ray (2015) showed that availability of phosphates and nitrates are the important factors that favor the abundance of cyanobacteria in ecosystems. In the forest land soils especially with dense vegetation (S4), the relatively high organic carbon content was related to the land use type, which 
plays a very important role in the soil enrichment by the organic matter and litter (Kooch et al., 2008). Despite their high organic matter content, these forests soils have the lowest number of cyanobacterial taxa. This finding was in harmony with that obtained by Vijayan and Ray (2015), who reported that the vegetation density causes a decrease in light intensity. These results highlighted that soil light condition could be influenced by different land uses. Indeed, the light is an important factor that contributes to the cyanobacterial and microalgal abundance and distribution in natural environments (̌̌eháková et al., 2011).

The obtained results show that cyanobacteria were found in all examined soils but they reveal a significant variation in their species richness. A comparative analysis of the total cyanobacteria richness showed a similarity with other works (Řeháková et al., 2011; Al-Sodany et al., 2018). This survey highlighted the existence of 26 taxa, distributed on 3 orders and 9 genera; with 3 species reported for the first time in Morocco (Phormidium priestleyi, Phormidium crassivaginatum, Pseudanbaena minima). This richness is very important and constitutes a substantial addition to soil cyanobacteria inventories around the world (35 taxa in Eastern Himalayas of India (Choudhary and Singh, 2013); 31 taxa in High altitude at Taif city of Saudi Arabia (AlSodany et al., 2018); 81 taxa in mountain tundras of the Polar and Subpolar Urals of Russia (Patova et al., 2018)).

The Oscillatoriales constitute the most diversified order, followed by Chroococcales and Nostocales. This result is in accordance with the findings of Reháková et al. (2011) who reported that the Oscillatoriales are generally more abundant in finer textured soils that contain relatively high concentrations of organic matter. In contrast, the order of Chroococcales may have increased with altitude because, as unicellular organisms with rapid growth rates, they do not require a stable substrate with a high organic matter content. Whereas, the Nostocales are usually thought to be able to colonize young undeveloped soils because of their ability to fix nitrogen, which might be the limiting nutrient (Kaštovská et al., 2005).

In addition, the Nostocales, represented in this study by Nostoc muscorum, are found in all sites but have larger thallus in wet high mountain soil. This observation is consistent with that of Reháková et al. (2011) who observed that Nostocales were predominated at high altitude. Indeed, they are better adapted to desiccation and cold conditions, due to their well-developed mucilaginous sheath. Nostoc species could also behave at high altitude because their biovolume is independent of the concentration of organic matter, unlike other species. Generally, this genus can usually colonize young undeveloped soils because of its ability to fix nitrogen (Whitton and Pott, 2012), which might be the limiting nutrient in these types of soils.

Six strains were successfully isolated in culture of soils in nutrient media. Pseudanabaena and Lyngbya strains were known by their potential toxicity (Shimizu, 2003; Olvera-Ramírez et al., 2010). However, the other isolated taxa can be considered by their high potential biotechnological value (Nostoc muscorum, Phormidium articulatum, Leptolyngbya sp and Synechocystis sp). In a recent work, Shariatmadari et al. (2013) showed that the application of the strains of Anabaena vaginicola and Nostoc sp increased the organic $\mathrm{C}$ and $\mathrm{N}$ content of the surface soil and enhanced plant growth and plant ion uptake; therefore, they are appropriate candidates for a good biofertilizer. Also, the work of Nonibala and Singh (2015) shows that Nostoc muscorum and Synechocystis sp have promising antifungal activity that can serve as promising biocontrol agents in current agricultural practices. Previous studies focusing on the role 
of microalgae in the removal of heavy metals from the soil showed that some cyanobacteria taxa such as Stigonema sp, Phormidium molle, Leptolyngbya sp and Synechococcus sp were resistant to heavy metals and thus used for the removal of soil contaminated by heavy metals (Rahman et al., 2011).

\section{Conclusion}

This exploratory survey provides a first inventory and data ecology of the cyanobacterial assemblage of soil crusts in a Moroccan mountainous region. This study reveals the existence of a significant cyanobacterial diversity (26 taxa) in the soils of five sampling sites with different land use and vegetation cover along an altitudinal gradient. The studied soils were characterized by significant cyanobacteria richness, with the presence of cosmopolitan and ubiquitous taxa (such as Phormidium crassivaginatum, Leptolyngbya faveolarum, Nostoc muscorum and Schizothrix sp).

Ultimately, the distribution of soil-cyanobacteria was mainly influenced by altitude, humidity and soils texture, land use and vegetation cover. Cyanobacteria composition and species richness were correlated to the soil physico-chemical characteristics especially nutrients content (ammonia nitrogen and available phosphorus), soils moisture, $\mathrm{pH}$ and conductivity.

In this first study, the soil-cyanobacterial inventory was far from being exhaustive in relation to the existing potential. Further investigations are necessary using an experimental approach based on soil culture in nutrient media and identification taxa by molecular methods. More field surveys will be necessary to complete and evaluate the effects of others environmental factors on the diversity, distribution and ecological trends of cyanobacteria in Moroccan terrestrial environments.

Acknowledgements This work was supported by the Water, Biodiversity, and Climate Change Laboratory, Faculty of Sciences Semlalia, University Cadi Ayyad, Marrakesh (Morocco). We would like to express also our gratitude to anonymous reviewers for their useful comments.

\section{REFERENCES}

[1] Abed, R. M., Dobretsov, S., Sudesh, K. (2009): Applications of cyanobacteria in biotechnology. - J. Appl. Microbiol 106(1): 1-12. https://doi:10.1111/j.13652672.2008.03918.x.

[2] Acea, M. J., Diz, N., Prieto-Fernandez, A. (2001): Microbial populations in heated soils inoculated with cyanobacteria. - Biol Fertil Soils 33(2): 118125.https://doi:10.1007/s003740000298.

[3] AFNOR (1975): Standard T90-1110. - Water Test: Determination of Total Kjeldahl Nitrogen.

[4] AFNOR (2000): Soil improvers and growing media. Preparation of samples for physical and chemical testing, determination of dry matter content, moisture content and laboratory compacted density. - French Association of Normalization, NF EN 13040.

[5] Al-Sodany, Y. M., Issa, A. A., Kahil, A. A., Ali, E. F. (2018): Diversity of Soil Cyanobacteria in Relation to Dominant Wild Plants and Edaphic Factors at Western Saudi Arabia. - ARRB 26(3): 1-14. https://doi:10.9734/ARRB/2018/40492.

[6] Anagnostidis, K., Komarek, J. (1990): Modern approach to the classification system of cyanophytes, 5-Stigonematales. - Algolo Stud 86: 1-74.

[7] Aubert, G. (1978): Soil Analysis Methods. - CRDP Edition, Marseille. 
[8] Bag, P., Ansolia, P., Mandotra, S. K., Bajhaiya, A. K. (2019): Potential of Blue-Green Algae in Wastewater Treatment. - In: Gupta, S. K., Bux, F. (eds.) Application of Microalgae in Wastewater Treatment. Springer, Cham. https://doi.org/10.1007/978-3030-13913-1_17.

[9] Belnap, J., Phillips, S. L., Witwicki, D. L., Miller, M. E. (2008): Visually assessing the level of development and soil surface stability of cyanobacterially dominated biological soil crusts. - Journal of Arid Environments 72(7): 1257-1264. DOI: 10.1016/j.jaridenv.2008.02.019.

[10] Belnap, J., Weber, B., Büdel, B. (2016): Biological Soil Crusts as an Organizing Principle in Drylands. - In: Weber, B. et al. (eds.) Biological Soil Crusts: An Organizing Principle in Drylands. Ecological Studies 226. Springer, Cham, pp. 3-13. https://doi.org/10.1007/978-3-319-30214-0_1.

[11] Blanco, Y., Prieto-Ballesteros, O., Gómez, M. J., Moreno-Paz, M., García-Villadangos, M., Rodríguez-Manfredi, J. A., ... Parro, V. (2012): Prokaryotic communities and operating metabolisms in the surface and the permafrost of Deception Island (Antarctica). - Environmental Microbiology 14(9): 2495-2510. https://doi.org/10.1111/j.14622920.2012.02767.x.

[12] Büdel, B., Dulic, T., Darienko, T., Rybalka, N., Friedl, T. (2016): Cyanobacteria and Algae of Biological Soil Crusts. - In: Weber, B. et al. (eds.) Biological Soil Crusts: An Organizing Principle in Drylands. Ecological Studies 226. Springer, Cham, pp. 55-80. DOI: 10.1007/978-3-319-30214-0_4.

[13] Choudhary, K. K., Singh, R. K. (2013): Cyanobacterial diversity along altitudinal gradient in Eastern Himalayas of India. - J. Algal Biomass Utln 4(2): 53-58.

[14] Davey, M. C., Rothery, P. (1993): Primary colonization by microalgae in relation to spatial variation in edaphic factors on Antarctic fell field soils. - J. Ecol 81: 335-343. https://doi.org/10.2307/2261503.

[15] Douma, M. (2010): Biodiversité des Cyanobactéries des zones humides continentales du Maroc: taxonomie, distribution géographique, écologie, phylogénie et potentiel toxique. $\mathrm{PhD}$ Thesis, Faculty of Sciences Semlalia, University of Cadi Ayyad Marrakech, Morocco.

[16] Douma, M., Loudiki, M., Oudra, B., Mouhri, K., Ouahid, Y., Francisca, F., del Campo, F. (2009): Taxonomic diversity and toxicological assessment of Cyanobacteria in Moroccan inland waters. - Rev. Sci. Eau 22(3): 435-449. https://doi.org/10.7202/037781ar.

[17] El Khalil, H., Schwartz, C., El Hamiani, O., Kubinick, J., Morel, J. L., Boularbah, A. (2013): Distribution of major elements and trace metals as indicators of technosolisation of urban and suburban soils. $\quad-\quad J$ Soils Sediments 13: 519530.https://doi.org/10.1007/s11368-012-0594-x.

[18] Garcia-Pichel, F., Felde, V. J. M. N. L., Drahorad, S. L., and Weber, B. (2016): Microstructure and Weathering Processes within Biological Soil Crusts. - In: Weber, B. et al. (eds.) Biological Soil Crusts: An Organizing Principle in Drylands. Ecological Studies 226. Springer, Cham, pp. 237-255. DOI: 10.1007/978-3-319-30214-0_13.

[19] Hackl, E., Bachmann, G., Zechmeister-Bolternstern, S. (2004): Microbial nitrogen turnover in soils under different types of natural forest. - Forest Ecol. Manage. 188: 101112.

[20] Haider, A. A., Haifaa, M. J. (2017): Effect of physicochemical factors on cyanobacteria biodiversity in some agricultural soil of Al-Diwaniyah City during spring period. - JGPT 2(9): 43-52.

[21] Haroni, S. A., Alifriqui, M., Ouhammou, A. O. (2009): La diversité floristique des pelouses humides d'altitude: cas de quelques sites du Haut Atlas Marocain. - Acta Botanica Malacitana 34: 91-106.

[22] Heckman, K. A., Anderson, W. B., Wait, D. A. (2006): Distribution and activity of hypolithic soil crusts in a hyperarid desert (Baja California, Mexico). - Biol Fertil Soils 43: 263-266.https://doi:10.1007/s00374-006-0104-7. 
[23] Hoffmann, L. (1989): Algae of terrestrial habitats. - Bot Rev 55(2): 77-105.

[24] Hu, Q., Sommerfeld, M., Jarvis, E., Ghirardi, M., Posewitz, M., Seibert, M., Darzins, A. (2008): Microalgal triacylglycerols as feedstocks for biofuel production: perspectives and advances. - Plant J 54(4): 621-639. https://doi: 10.1111/j.1365-313X.2008.03492.x.

[25] ISO 10260 (1992): Water Quality, Measurement of Biochemical Parameters; Spectrometric Determination of the Chlorophyll-a Concentration. - Beruth Verlag, Berlin.

[26] Janatková, K., Řeháková, K., Doležal, J., Šimek, M., Chlumská, Z., Dvorský, M., Kopecký, M. (2013): Community structure of soil phototrophs along environmental gradients in arid Himalaya. - Environ. Microbiol 15(9): 2505-2516. https://doi.org/10.1111/1462-2920.12132.

[27] Kaštovská, K., Elster, J., Stibal, M., Šantrůčková, H. (2005): Microbial assemblages in soil microbial succession after glacial retreat in Svalbard (High Arctic). - Microb Ecol 50: 396-407. https://doi.org/10.1007/s00248-005-0246-4.

[28] Kobbia, I. A., Shabana, E. F. (1988): Studies on the soil algal flora of Egyptian Bahariya Oasis. - Egypt. J. Bot 31: 1-3.

[29] Komarek, J. (2013): Cyanoprokaryota 3. Heterocytous genera. - In: Ettl, H., Gartner, G., Heynig, H., Mollenhauer, D. (eds.) Süsswasserflora von Mitteleuropa. Band 19/3. Spektrum Verlag, Heidelberg, pp. 1-1087.

[30] Komarek, J., Anagnostidis, K. (1998): Cyanoprokaryota 1. Chroococcales. - In: Ettl, H., Gartner, G., Heynig, H., Mollenhauer, D. (eds.) Süsswasserflora von Mitteleuropa. Vol. 19/1. Spektrum Verlag, Heidelberg, pp. 1-548.

[31] Komarek, J., Anagnostidis, K. (2005): Cyanoprokaryota 2. Oscillatoriales, Vol. 19/2. In: Budel, B., Gartner, G., Krienitz, L., Schagerl M. (eds.) Süsswasserflora von Mitteleuropa. Spektrum Verlag, Heidelberg, pp. 1-757.

[32] Kooch, Y., Jalilvand, H., Bahmanyar, M. A., Pormajidian, M. R. (2008): The use of principal component analysis in study of physical, chemical and biological soil properties in southern Caspian forests (north of Iran). - Pakistan J Biol Sci 11(3): 366-372. https://doi:10.3923/pjbs.2008.366.372.

[33] Kotai, J. (1972): Instructions for Preparation of Modified Nutrient Solution Z8 for Algae. - Norwegian Institute for Water Research, Oslo.

[34] Lin, C. S., Chou, T. L., Wu, J. T. (2013): Biodiversity of soil algae in the farmlands of mid-Taiwan. - Bot Stud 54(1): 41. https://doi.org/10.1186/1999-3110-54-41.

[35] Liu, Y., Xing, Z., Yang, H. (2017): Effect of biological soil crusts on microbial activity in soils of the Tengger Desert (China). - J. Arid. Environ 144: 201-211. http://dx.doi.org/10.1016/j.jaridenv.2017.04.003.

[36] Loudiki, M., Oudra, B., Sabour, B., Sbiyyaa, B., Vasconcelos, V. (2002): Taxonomy and geographic distribution of potential toxic Cyanobacterial strains in Morocco. - Ann. Limnol 38(2): 101-108.https://doi.org/10.1051/limn/2002008.

[37] Maestre, F. T., Bowker, M. A., Cantón, Y., Castillo-Monroy, A. P., Cortina, J., Escolar, C., Lázaro, R.,Martínez, I. (2011): Ecology and functional roles of biological soil crusts in semi-arid ecosystems of Spain. - J. Arid. Environ 75(12): 1282-1291. https://doi.org/10.1016/j.jaridenv.2010.12.008.

[38] Malam Issa, O., Defarge, C., Bissonnais, Y. L., Martin, B., Duval, A., Bruand, A., D'Acqui, L. P., Nodernberg, S., Annerman, M. (2007): Effects of the inoculation cyanobacteria on the microstructure and the structural stability of a tropical soil. - Plant Soil 290(1): 209-219. https://doi.org/10.1007/s11104-006-9153-9.

[39] Mansour, H. A., Shaaban, A. S. (2010): Algae of soil surface layer of Wadi Al-Hitan protective area (world heritage station), El-Fayum depression, Egypt. - Am. J. Sci 6(8): 243-255.

[40] Meliho, M., Khattabi, A., Mhammdi, N., Hongming, Z. (2016): Impact of land use and vegetation cover on risks of erosion in the Ourika watershed (Morocco). - American Journal of Engineering Research (AJER) 5(9): 75-82. 
[41] Muñoz-Martín, M. Á., Becerra-Absalón, I., Perona, E., Fernández-Valbuena, L., Garcia-Pichel, F., Mateo, P. (2019): Cyanobacterial biocrust diversity in Mediterranean ecosystems along a latitudinal and climatic gradient. - New Phytologist 221(1): 123-141. https://doi.org/10.1111/nph.15355.

[42] Nduwayo, E., Khattabi, A., El Abidine, A., Ouhammou, A. (2017): Evaluation de l'état de formations végétales forestières dans le bassin versant de l'Ourika dans une optique de restauration des espaces dégradés. - Revue Paysages Géographiques 4: 19.

[43] Nemergut, D. R., Anderson, S. P., Cleveland, C. C., Martin, A. P., Miller, A. E., Seimon, A., Schmidt, S. K. (2007): Microbial community succession in an unvegetated, recently deglaciated soil. - Microb Ecol 53: 110-122. https://doi.org/10.1007/s00248-006-9144-7.

[44] NF ISO 10390. (1992): Soil quality - Determination of pH. - ISO, Geneva.

[45] Nonibala, K., Singh, N. I. (2015): Screening of cyanobacteria from the soil of paddy field for biotechnological applications. - J. Mycopathol. Res 53(1): 55-58.

[46] Olsen, S. R., Cole, C. V., Watanabe, F. S., Dean, L. A. (1954): Estimation of available phosphorus in soils by extraction with sodium bicarbonate. - US Dep. Agric. Circ 939: 18-19.

[47] Olvera-Ramírez, R., Centeno-Ramos, C., Martínez-Jerónimo, F. (2010): Toxic effects of Pseudanabaena tenuis (Cyanobacteria) on the cladocerans Daphnia magna and Ceriodaphnia dubia. - Hidrobiológica 20: 203-212.

[48] Ouhammou, A. (2005): Flore et végétation du Parc National de Toubkal (Haut-Atlas de Marrakech, Maroc): typologie, écologie et conservation. - Th. D'état, Université Cadi Ayyad, Marrakech.

[49] Patova, E. N., Novakovskaya, I. V., Deneva, S. V. (2018): The influence of edaphic and orographic factors on algal diversity in biological soil crusts on bare spots in the polar and subpolar Urals. - Eurasian J. Soil Sci 51(3): 309-320. https://doi.org/10.1134/S1064229318030109.

[50] Quesada, A., Nieva, M., Leganés, F., Ucha, A., Martín, M., Prosperi, C., FernándezValiente, E. (1998): Acclimation of Cyanophytal communities in rice fields and response of nitrogenase activity to light regime. - Microb Ecol 35: 147155.https://doi.org/10.1007/s002489900069.

[51] Rahman, M. A., Soumya, K. K., Tripathi, A., Sundaram, S., Singh, S., Gupta, A. (2011): Evaluation and sensitivity of cyanobacteria, Nostoc muscorum and Synechococcus PCC 7942 for heavy metals stress-a step toward biosensor. - Environ Toxicol Chem 93(10): 1982-1990. https://doi.org/10.1080/02772248.2011.606110.

[52] Řeháková, K., Chlumská, Z., Doležal, J. (2011): Soil Cyanobacterial and microalgal diversity in dry mountains of Ladakh, NW Himalaya, as related to station, altitude, and vegetation. - Microb Ecol 62: 337-346. DOI: 10.1007/s00248-011-9878-8.

[53] Rejmánková, E., Komárek, J., Komárková, J. (2004): Cyanobacteria-a neglected component of biodiversity: patterns of species diversity in inland marshes of northern Belize (Central America). - Diversity and Distributions 10(3): 189-99. https://doi.org/10.1111/j.1366-9516.2004.00077.x.

[54] Rivera-Aguilar, V., Montejano, G., Rodriguez-Zaragoza, S., Duran-Diaz, A. (2006): Distribution and composition of cyanobacteria, mosses and lichens of the biological soil crusts of the Tehuacan Valley, Puebla, Mexico. - J. Arid. Environ 67: 208225.https://doi:10.1016/j.jaridenv.2006.02.013.

[55] Rossi, F., Li, H., Liu, Y., De Philippis, R. (2017): Cyanobacterial inoculation (cyanobacterisation): perspectives for the development of a standardized multifunctional technology for soil fertilization and desertification reversal. - Earth-Science Reviews 171: 28-43. https://doi.org/10.1016/j.earscirev.2017.05.006.

[56] Singh, H., Khattar, J. S., Ahluwalia, A. S. (2014): Cyanobacteria and agricultural crops. Vegetos 27(1): 37-44. DOI: 10.5958/j.2229-4473.27.1.008. 
[57] Singh, J. S., Kumar, A., Rai, A. N., Singh, D. P. (2016): Cyanobacteria: a precious bioresource in agriculture, ecosystem, and environmental sustainability. - Front Microbiol 7: 529. DOI: $10.3389 /$ fmicb.2016.00529.

[58] Shariatmadari, Z., Riahi, H., Seyed Hashtroudi, M., Ghassempour, A., Aghashariatmadary, Z. (2013): Plant growth promoting cyanobacteria and their distribution in terrestrial habitats of Iran. - J. Soil Sci. Plant Nutr 59(4): 535547.http://dx.doi.org/10.1080/00380768.2013.782253.

[59] Shimizu, Y. (2003): Microalgal metabolites. - Curr Opin Microbiol 6(3): 236-243. https://doi:10.1021/cr00021a002.

[60] Soltner, D. (2005): The Bases of Plant Production. The Soil and Its Improvement. Vol. I, $24^{\text {th }}$ Ed. - Science Collection and Agricultural Techniques, Sainte-Gemmessur-Loire.

[61] Vijayan, D., Ray, J. G. (2015): Ecology and diversity of Cyanobacteria in Kuttanadu paddy wetlands, Kerala, India. - Am. J. Plant Sci 6: 2924-2938. DOI: 10.4236/ajps.2015.618288.

[62] Whitton, B. A., Pott, M. (2012): The Ecology of Cyanobacteria II: Their Diversity in Time and Space. - Springer, Dordrecht. https://doi:10.1007/978-94-007-3855-3_10.

[63] Zancan, S., Trevisan, R., Paoletti, M. (2006): Soil algae composition under different Agro-Ecosystems in North-Eastern Italy. - Agr Ecosyst Environ 112(1): 1-12. https://doi.org/10.1016/j.agee.2005.06.018.

[64] Zhang, B., Zhang, Y., Downing, A., Niu, Y. (2011): Distribution and composition of cyanobacteria and microalgae associated with biological soil crusts in the Gurbantunggut Desert, China. - Arid Land Res Manag 25(3): 275293.https://doi:10.1080/15324982.2011.565858. 